\title{
Pola Asuh Orang Tua Kristen Terhadap Anak Dalam Menghadapi Tantangan Kemajuan Zaman
}

\author{
Asmat Purba $^{\mathrm{a}}$, Alon Mandimpu Nainggolan ${ }^{\mathrm{b}}$
}

\author{
Teknik Informatika Politeknik TEDC Bandung ${ }^{a}$ \\ Institut Agama Kristen Negeri Manado ${ }^{b}$ \\ asmatpurba805@gmail.com ${ }^{a}$ \\ nainggolanalon1008@gmail.com ${ }^{b}$
}

\begin{abstract}
Abstrak
Penelitian ini bertujuan untuk mengetahui pola asuh orang tua Kristen terhadap anak dalam menghadapi tantangan kemajuan zaman, sehingga melalui penulisan artikel ini dapat memberikan gambaran kepada orang tua agar mereka memiliki pola asuh yang baik dan menjadi orang tua yang berperan sebagai guru yang patut diteladani oleh anak-anaknya. Untuk mewujudkan penelitian ini, maka penulis memilih metode penelitian kualitatif yang bersifat deskriptif dengan studi kepustakaan. Melalui penelitian ini ditemukan bahwa zaman dimana kita hidup saat ini akan terus mengalami perubahan dan perkembangan, namun moral dan keimanan manusia semakin menurun. Perubahan atau perkembangan yang paling tren masa kini ialah perkembangan teknologi seperti smartphone. Orang tua adalah guru dalam keluarga yang seyogianya memiliki pola asuh yang baik agar dapat mengantisipasi dan menghadapi tantangan kemajuan zaman yang sedang berkembang saat ini agar anak-anak tetap berkembang secara utuh dalam rasa takut akan Tuhan dan mencintai gereja-Nya. Kemajuan zaman dapat berdampak buruk (negatif) bagi anak-anak jikalau orang tua tidak menerapkan pola asuh yang baik terhadap anak, dan sebaliknya dapat juga berdampak baik (positif) apabila orang tua mendemonstrasikan pola asuh yang baik terhadap anak. Lebih mudah menjadi guru bagi anak sendiri daripada menjadi guru bagi orang lain. Dalam praktiknya orang tua Kristen dapat menerapkan sepuluh usulan rancang bangun pendidikan rohani anak oleh orang tua untuk menghadapi kemajuan (tren) zaman di abad ke-21.
\end{abstract}

Kata kunci : Pola asuh, orang tua Kristen, guru, tantangan kemajuan zaman

\section{PENDAHULUAN}

Kemajuan zaman pada masa kini ditandai oleh munculnya berbagai media sosial yang sangat menggiurkan. Hampir semua anak-anak senang bermain digital yakni smartphone, bahkan ketika anak baru berumur 1,5 tahun sudah dapat memainkan permainan dalam smartphone dan ketika smartphone diminta dari seorang bayi, dia dapat memperlihatkan reaksi penolakan dengan tangisan yang keras agar smartphone yang dia pegang tidak diambil dari padanya. Smartphone dengan segala perangkat / fitur-fitur yang ada di dalamnya dengan cepat dapat dikuasai oleh anak-anak tanpa harus terlebih dahulu diajarkan oleh orang tua. Dapat dikatakan kecepatannya dapat mengalahkan orang dewasa. Selain game dalam smartphone, anak-anak juga sudah senang melihat tiktok, snack video, youtube dan lainnya yang di dalamnya ada sejumlah tontonan menarik. Hal senada dikemukakan oleh Siregar dalam tulisannya yang berjudul "anak rewel dan bikin sibuk? diberi saja handphone...solusi jitukah" (Siregar, 
2018). Itu berarti teknologi seperti smartphone dengan sangat mudah dikuasai dan menguasai anak-anak yang tengah berkembang dan bertumbuh.

Orang tua dan anak-anak ialah dua generasi yang sangat berbeda. Jika orang tua tidak mengerti psikologi anak, maka sangat mungkin terjadi konflik antara orang tua dengan anak (Sriyanti, 2014:7). Pola pengasuhan yang diterima atau dialami oleh orang tua seringkali dijadikan patokan untuk mengasuh anak-anak mereka kemudian padahal generasi dan perkembangan teknologi anak sudah jauh berbeda dengan orang tua mereka. Orang tua seyogianya selalu melindungi dan menjaga supaya generasi anak (penerus) tetap berpedoman pada tujuan hidup orang Kristen (Ul. 6:4-9). Rasul Paulus mengemukakan bahwa setiap orang Kristen harus selalu berfokus pada tujuan hidup. "...supaya kamu tiada beraib dan tiada bernoda. Sebagai anak-anak Allah yang tidak bercela di tengah-tengah angkatan (generasi) yang bengkok hatinya dan yang sesat ini, sehingga kamu bercahaya di antara mereka seperti bintang-bintang di dunia, sambil berpegang pada firman kehidupan..." (Fil. 2:15-16). Spiritualitas sangat berperan dalam kehidupan gereja dan anak-anak. Tanpa spiritualitas iman orang Kristen tidak akan bersinar, lemah tanpa kekuatan, dan tidak menjadi ciptaan baru (Nainggolan, 2008:31).

Apabila orang tua tidak melakukan pola asuh yang baik dan benar terhadap anakanak mereka, maka teknologilah yang mendidik mereka dan hasilnya sesuai dengan keinginannya. Setelah teknologi yang mengambil alih pendidikan anak, maka terjadilah kehancuran bagi generasi berikutnya. Orang tua harus bisa mengemas pesan Alkitab dan menyampaikannya kepada anak-anak mereka. Anak-anak masih lugu dan masih mudah dikendalikan oleh orang dewasa. Namun, orang tua juga seyogianya menyadari dan menghidupi tugas, peran dan tanggung jawabnya sebagai guru dalam konteks keluarga. Dapat mendemonstrasikan peran sebagai pengajar, pendidik, gembala, sahabat, dan lainnya bagi anak. Dalam hal ini, setiap orang tua yang percaya kepada Tuhan sebagai Tuhan dan Juruselamat di tengah keluarga harus mengetahui bahwa anak merupakan pekerjaan rumah (PR) yang Allah anugerahkan dalam pendidikan anak. Pendidikan anak tidak sekadar mengajarkan dan mewariskan nilai-nilai kehidupan, tetapi mengenal kebenaran Allah dan hidup bersama-Nya (Maz. 127:5). Pendidikan bagi anak mengajarkan mereka jalan kehidupan sejati, jalan yang mengantar kepada juru selamat, menunjukkan kebenaran, mengenal pengetahuan dan hikmat. Pendidikan terhadap anak seyogianya berpusat pada Firman Allah yang adalah sumber kebenaran mutlak (Daeli dan Nainggolan: 2020:45-47).

Orang tua yang melarang anak bermain smartphone harus diikuti dengan keteladanan dari orang tua (Ismail, 2014). Fenomena tengah terjadi pada saat ini, secara khusus di konteks Kristen telah nampak terjadinya gelombang eksodus generasi muda (penerus) yang telah meninggalkan gereja, bahkan telah meninggalkan iman mereka karena poa asuh orang tua dinilai tidak relevan dan tidak menjawab tantangan zaman. Nampaknya para orang tua mengalami kewalahan mengikuti lajunya percepatan kemajuan yang dialami generasi muda di abad ke-21 ini.

Yang menjadi rumusan permasalahan dalam penelitian dan penulisan artikel ini adalah bagaimana pola asuh orang tua Kristen bagi anak-anak dalam menghadapi tantangan kemajuan zaman? Artikel ini akan menguraikan sejumlah bahasan penting tentang pola asuh sesuai prinsip firman Tuhan, keteladanan orang tua selama proses pengasuhan, mengerti psikologi perkembangan anak, memahami generasi orang tua dan generasi anak kita, mengenali tantangan masa kini, dan mengantisipasi kemajuan (tren) zaman. Selanjutnya, akan diuraikan pentingnya menata ulang pendidikan Kristen kepada generasi muda, orang tua dan gereja bekerjasama mendidik generasi muda, 
menerapkan prinsip pembelajaran yang mudah dimengerti, mereformasi sistem pembelajaran, dan rancang bangun pendidikan rohani anak oleh orang tua menghadapi kemajuan (tren) zaman.

Daeli dan Nainggolan (2020:45-57) mengemukakan bahwa masa anak adalah masa emas dan terpenting. Mengapa? Karena masa anak-anak merupakan dasar bangunan yang turut menentukan masa mendatang, masa yang paling diingat, daya menerima informasi tinggi, mencontoh sangat kuat, hati mereka masih polos, memiliki spontanitas, dan lain-lain. Oleh karena itu, mereka harus diajar oleh orang tua dengan pola asuh yang baik untuk membenci dosa dan diupayakan agar mengasihi Tuhan dari sejak kecilnya.Yang dimaksud dengan anak di sini adalah terutama golongan usia dini (di bawah 7 tahun).

\section{METODE}

Metode penelitian yang dipilih dalam artikel ini adalah metode kualitatif yang bersifat deskriptif, dengan studi literatur (kepustakaan). Untuk mengetahui dan memahami tren / perkembangan zaman maka pemanfaatan literatur terkait seperti laporan penelitian, media massa, media elektronik, jurnal, artikel dan lainnya akan memberikan deskripsi, selain juga untuk mengetahui persoalan tantangan zaman dan kemunduran iman generasi muda sebagai akibatnya. Penelitian ini memanfaatkan bukubuku monograf, referensi, teks, dan jurnal ilmiah. Hal senada dikemukakan oleh Nainggolan dan Labobar (2020: 113-125) bahwa pengumpulan data dilaksanakan secara bertahap dan melalui studi dokumen oleh peneliti dengan melakukan penelusuran dan penggalian terhadap jurnal, laporan penelitian, dan buku-buku Pendidikan Kristen yang terkait dengan topik yang sedang diteliti. Hal ini bermanfaat untuk membangun konsep tentang pola asuh orang tua Kristen. Jika selanjutnya ada data yang kurang relevan atau tidak sesuai, peneliti masih bisa menggunakan data utama dan pendukung lain yang ada.

Data yang terkumpul akan dianalisis oleh penulis. Konsep-konsep dianalisis dengan cara memperhatikan keterkaitan, kesamaan, dan kesesuaian dengan topik penelitian. Analisis data dilaksanakan secara induktif, melalui beberapa tahapan yakni, reduksi data, penyajian data, verifikasi dan penarikan kesimpulan (Sugiyono, 2011:339343). Selanjutnya, penulis akan menguraikan temuan penelitian, yakni pola asuh orang tua Kristen terhadap anak dalam menghadapi tantangan kemajuan zaman. Di dalamnya penulis akan membahas hasil penelitian. Kajian terhadap beberapa sumber literatur terpercaya, relevan dan terbaru diperlukan untuk dapat mengemukakan sebuah konsep baru. Akhirnya, penulis akan menyimpulkan seluruh rangkaian penelitian dari awal sampai akhir dengan metode kualitatif yang bersifat deskriptif, dengan studi literatur (library research) sebagai jawaban atas rumusan permasalahan (pertanyaan penelitian), menyajikan ucapan terima kasih, keterbatasan penelitian dan rekomendasi bagi peneliti selanjutnya dengan topik yang sama (Nainggolan, Harefa: 2020:1-15).

\section{HASIL DAN PEMBAHASAN}

\section{Pola Asuh Sesuai Prinsip Firman Tuhan}

Ada banyak buku yang menuliskan pola asuh anak. Namun penulis ingin sekali mengusulkan bahwa pola asuh kristiani harus bersumber dari Alkitab. Alkitab dengan jelas memberikan nasehat bagi para orang tua dalam mengajar dan mendidik keturunan (anak-anak) mereka. Hal ini senada dengan pandangan Nainggolan dan Janis bahwa pendidikan terhadap anak, secara khusus dalam aspek iman tidak lepas dari Firman 
Allah (Alkitab), karena pada dasarnya pendidikan iman (spritualitas) dalam lingkungan Pendidikan Agama Kristen di gereja, sekolah, masyarakat dan keluarga bersumber dari Firman Allah. (2020: 158; 2 Tim. 3:16). Kita perlu menyepakati bahwa orang tua adalah guru yang memiliki peran dan fungsi yang plural dan anak-anak di rumah adalah murid yang setiap hari bersama-sama dan melakukan pengajaran. Sadar atau tidak, orang tua merupakan sosok guru di tengah keluarga. Orang tua disebut guru (Teacher) dalam konteks keluarga. Tan Giok Lie merinci tugas seorang guru (orang tua) ketika melaksanakan tugasnya sebagai guru (Teacher) dalam tabel berikut ini.

Ada tujuh komponen mengajar dalam shema (Ul.6:1-9). Kita perlu menyimak dan mempelajari apa yang dituliskan secara rinci di bawah ini (Lie, 2017; Kinnaman, 2011);

\section{Tabel 1.1. Tujuh Komponen Mengajar Dalam Shema}

\begin{tabular}{|c|c|c|}
\hline No & en Mengajar & Shema \\
\hline 01 & $\begin{array}{l}\text { T-- Teacher } \\
\text { (Guru / Pendidik yang } \\
\text { merancang seluruh } \\
\text { komponen pengajaran) }\end{array}$ & $\begin{array}{l}\text { Ayat 2-3 - "supaya seumur hidupmu engkau (orang } \\
\text { tua) dan anak cucumu takut akan TUHAN, } \\
\text { Allahmu... Maka dengarlah, hai Israel (orang tua)! } \\
\text { Lakukanlah itu dengan setia, Ul.6:5-6a: "Apa yang } \\
\text { kuperintahkan kepadamu pada hari ini haruslah } \\
\text { engkau (orang tua) perhatikan, haruslah engkau } \\
\text { (orang tua) mengajarkannya...kepada anak- } \\
\text { anakmu..." }\end{array}$ \\
\hline 02 & $\begin{array}{l}\text { yang } \\
\text { bahan } \\
\text { yang } \\
\text { n) }\end{array}$ & $\begin{array}{l}\text { Ulangan 6:1 "Inilah perintah, yakni ketetapan dan } \\
\text { peraturan, yang aku ajarkan kepadamu atas perintah } \\
\text { TUHAN, Allahmu, untuk dilakukan di negeri, ke } \\
\text { mana kamu pergi untuk mendudukinya," }\end{array}$ \\
\hline 03 & $\begin{array}{l}\text { ig } \\
\text { lari awal } \\
\text { ik untuk murid / }\end{array}$ & $\begin{array}{l}\text { Ayat 6a---"Apa yang kuperintahkan (these } \\
\text { commandments) kepadamu pada hari ini..." yang } \\
\text { intinya terkandung dalam ayat 5: "Kasihilah } \\
\text { TUHAN, Allahmu, dengan segenap hatimu dan } \\
\text { dengan segenap jiwamu dan dengan segenap } \\
\text { kekuatanmu."Bdk. Matius 22:37-40) } \\
\text { Ayat 3b---"supaya baik keadaanmu, dan supaya } \\
\text { kamu menjadi sangat banyak..." }\end{array}$ \\
\hline 04 & $\begin{array}{l}\text { / Individual } \\
\text { eserta didik) }\end{array}$ & $\begin{array}{l}\text { Ayat 2a--“"anak cucumu (generasi-generasi } \\
\text { selanjutnya)" } \\
\text { Ayat 7b---"kepada anak-anakmu di rumahmu" }\end{array}$ \\
\hline 05 & $\begin{array}{l}\text { ic } \\
\text { nt } \\
\text { an secara } \\
\text { ag } \\
\text { efektivitas } \\
\text { an) }\end{array}$ & $\begin{array}{l}\text { Ayat 1b---"di negeri, ke mana kamu pergi untuk } \\
\text { mendudukinya (lingkungan makro)" } \\
\text { Ayat 6, 7b-9---"duduk di rumahmu,...dalam } \\
\text { perjalanan, (beraktivitas di dalam dan di luar rumah } \\
\text { sewaktu siang)...berbaring dan bangun (di kamar } \\
\text { tidur di waktu malam), pintu gerbang (di halaman } \\
\text { depan rumah) (lingkungan mikro)" }\end{array}$ \\
\hline 06 & & 7-9---“mengajarkannya \\
\hline
\end{tabular}




\begin{tabular}{|l|l|l|}
\hline $\begin{array}{l}\text { Activities (Aktivitas } \\
\text { pendidikan yang } \\
\text { meliputi pengalaman } \\
\text { pembelajaran dan } \\
\text { variasi metode } \\
\text { mengajar) }\end{array}$ & $\begin{array}{l}\text { kepada anak-anakmu dan membicarakannya apabila } \\
\text { engkau duduk di rumahmu, apabila engkau sedang } \\
\text { dalam perjalanan, apabila engkau berbaring dan } \\
\text { apabila engkau bangun. Haruslah juga engkau } \\
\text { mengikatkannya sebagai tanda pada tanganmu dan } \\
\text { haruslah itu menjadi lambang di dahimu, dan } \\
\text { haruslah engkau menuliskannya pada tiang pintu } \\
\text { rumahmu dan pada pintu gerbangmu." }\end{array}$ \\
\hline 07 & $\begin{array}{l}\text { Ayat 3b---"supaya baik keadaanmu, dan supaya } \\
\text { kamu menjadi sangat banyak, seperti yang } \\
\text { dijanjikan TUHAN, Allah nenek moyangmu, } \\
\text { kepadamu di suatu negeri yang berlimpah-limpah } \\
\text { susu dan madunya." }\end{array}$ \\
$\begin{array}{l}\text { (Hasil pengajaran } \\
\text { pendidik yang terlihat } \\
\text { dari kualitas } \\
\text { pembelajaran murid / } \\
\text { peserta didiknya) }\end{array}$ & \multicolumn{2}{|l}{} \\
\hline
\end{tabular}

Tabel 1.1 merupakan penjelasan shema dalam Ulangan pasal 6 ayat 1-9 yang diuraikan sebagai tugas guru (orang tua) mesti diperhatikan dengan seksama agar dapat dilakukan setiap hari. Meskipun kegiatan ini sulit dilakukan namun jika ada komitmen dari orang tua, maka ini dapat diterapkan dengan baik. Kasih kepada Allah adalah merupakan daya dorong untuk melakukan kegiatan ini (Mat. 22:37-39; Kel. 20:1-17). Tanpa mengasihi Allah, kegiatan pengajaran anak di keluarga sesuai dengan Shema Ulangan 6:1-9 tidak akan bisa terlaksana dengan baik. Terkait dengan kasih kepada Allah, Pazmino mengemukakan: Kasih kepada Allah (vertikal) diekspresikan, didemonstrasikan di dalam ketaatan dan kesetiaan terhadap perintah / ketetapan Allah Tritunggal dan di dalam wujud memberikan diri secara totalitas. Mengajar dan mendidik generasi penerus berarti senantiasa mengarahkan dan menantang para pendengar untuk memberikan tanggapan hidup secara utuh bagi Tuhan dalam wujud pengabdian sepenuhnya. Pengajaran seperti ini adalah tugas dan tanggung jawab orang tua secara khusus, akan tetapi tujuan ini juga merupakan tujuan dari semua bentuk pendidikan (Pazmino, 2012).

Purba mengemukakan bahwa orang tua adalah pribadi yang sangat primer untuk mengajar dan mendidik anak di tengah keluarga. Eksistensi orang tua ialah sebagai pelaku / pendidik utama dan pertama dalam pendidikan bagi anak. Oleh sebab itu kehadirannya secara fisik dan kualitas kepribadiannya sangat mempengaruhi dalam mewujudkan pendidikan anak di tengah keluarga. Orang tua harus mempunyai mutu yang cukup memadai, disebabkan orang tua merupakan salah satu pengajar dan pendidik Kristen yang sangat signifikan, strategis dan banyak mengambil peran dalam proses pendidikan di tengah keluarga. Mutu orang tua, misalnya spritualitas, kepribadian, kedewasaan, wawasan dan sebagainya merupakan hal yang sangat penting untuk memastikan anak-anak yang dididiknya juga bermutu seperti dirinya. Orang tua adalah pendidik Kristen di konteks keluarga (Purba, 2020). Itu sebabnya, pendidikan anak tidak dapat diserahkan secara totalitas kepada gereja, sekolah atau masyarakat, melainkan menjadikannya sebagai mitra untuk mengasuh anak agar menghasilkan pribadi unggul. 


\section{Keteladanan Orang Tua Selama Proses Pengasuhan}

Dalam sebuah ceramah keluarga, seorang pembicara memperlihatkan sebuah video yang berdurasi pendek. Tayangan itu menggambarkan keadaan orang tua di hadapan anak-anak. Orang tua melarang anak bermain gadget atau handphone dan terlihat anak-anak pun patuh kepada orang tua. Tetapi kemudian orang tua menggunakan handphone secara tersembunyi dan kemudian anak-anak juga pura-pura membaca buku pelajarannya padahal dalam buku tersebut ada handphone yang sedang aktif. Dari mana anak-anak belajar berbohong? Bisa dari orang tua dan bisa dari lingkungan. Artinya pendidikan keluarga yang demikian itu sudah bisa dikatakan gagal karena orang tua tidak memberikan keteladanan, tidak sesuainya kata dan tindakan orang tua. Orangtua harus menyadari bahwa anak itu adalah seorang pelajar cepat. Ia cepat menangkap contoh. Sebenarnya setiap anak pada dasarnya memang mudah untuk menyerap contoh dan cepat belajar dari teladan / contoh. Anak belajar dengan memakai pancainderanya, apa yang dia lihat, apa yang dia dengar, dan apa yang dia rasakan. Teladan memang mempunyai daya yang kuat baik bagi anak kecil maupun orang dewasa. Teladan memang mudah menular. Apapun yang diperbuat oleh orang tua bisa jadi diamati dan ditiru oleh anak-anak. Apabila mengetahui dan menyadari hal yang demikian, maka seyogianya akan berhati-hati supaya yang ditularkan itu bukan teladan yang buruk (Ismail, 2014; Sidjabat 2008: 3-9). Terkait dengan keteladanan Pazmino mengemukakan bahwa melalui pengajaran dan keteladanan dari para pendidik (orang tua), peserta didik dipanggil untuk mengerti, bertumbuh dan menaati firman Allah yang dinyatakan. Sementara itu, pendidik dimotivasi untuk bertekun dan terus menerus mengajar, maka diharapkan bahwa murid akan transparan / terbuka dan mau menerima pengajaran dari para pengajar atau pendidik mereka.

Beberapa perikop Alkitab lainnya, terutama Kitab Amsal, memberikan perintahperintah yang jelas bagi anak-anak agar memperhatikan ajaran dari orang tua mereka . Para pendidik utama di dalam konteks kehidupan orang Yahudi adalah orang tua. Pendidikan membutuhkan perencanaan, implementasi dan evaluasi terhadap pengalaman-pengalaman edukasional . Upaya yang disengaja dari pendidikan Kristen melibatkan upaya untuk membagikan isi pengajaran yang alkitabiah, menarik implikasinya terhadap kehidupan riil, dan menyarankan cara-cara tentang bagaimana memberikan respons yang tepat (Pazmino, 2012). Ide serupa ditekankan di dalam Yakobus 2:14-17. Keluarga adalah awal dari pendidikan terhadap anak, disebabkan dari dalam konteks keluarga pelbagai hal: watak, sifat, iman, karakter, perangai, kebiasaan dan lainnya yang didemontrasikan, diperoleh oleh anak. Intinya, pendidikan bagi anak bersumber dari orang tua; anak akan melihat, mendengar, meniru apa yang diinderai pada orang tua. Apa yang dilihat dan rasakan diserap yang selanjutnya membuahkan sebuah tindakan nyata. Keteladanan orang tua jauh lebih berpengaruh daripada nasihatnasihat yang disampaikan (Purba, 2020). Keteladanan hidup meneguhkan pengajaran dan sebaliknya pengajaran meneguhkan keteladanan hidup. Dua aspek penting yang tidak dapat dipisahkan ketika orang tua mendidik anak di tengah keluarga.

Sebenarnya apa yang dibutuhkan anak dari orang tua mereka? Apakah hanya kebutuhan fisik semata? Anak-anak membutuhkan keteladanan dari orang yang mereka hormati yaitu orang tua. Anak-anak terus mencari-cari apakah ada orang dewasa yang patut mereka teladani? Anak-anak yang sudah terbiasa dengan gadget akan memperoleh "keteladanan" dari tontonannya setiap hari, apakah itu baik atau tidak. Bahasa anakanak di rumah dipengaruhi oleh media sosial yang mereka tonton. Anak-anak berpikir bahwa hidup ini sama seperti yang dilihatnya. Tidak heran anak-anak pun menggunakan 
bahasa itu dalam kehidupan sosialnya. Kebiasaan orang tua ialah menasehati anak-anak padahal anak-anak lebih membutuhkan keteladanan dari kata-kata nasehat.

Lingkungan, agen yang paling dominan mempengaruhi pembentukan watak, iman dan tata nilai ialah keluarga asal (the family of origin). Sebelum anak menerima pengaruh dari teman sebaya, guru sekolah Minggu, masyarakat, dan lain-lain . Setiap keluarga memiliki tipe keluarga (apakah itu tipe keluarga berkepribadian kacau, kuasa/otoriter, mengekang, simbiotik atau seimbang) yang akan memengaruhi kepribadian dan watak anak. Dengan kata lain, setiap keluarga yang ada membentuk kepribadiannya sendiri, yang kemudian diwariskan kepada anak-anak (Sidjabat, 2008:3). Dalam hal inilah orangtua harus menjadikan ajaran dan gaya hidup Tuhan Yesus Kristus sebagai teladan agar mampu mendemonstrasikan keteladanan terhadap anak-anaknya.

\section{Orang Tua Mengerti Psikologi Perkembangan Anak}

Sidjabat dalam buku Membesarkan anak dengan kreatif menyinggung dalam pendahuluan bukunya tentang pemaparan gagasan pandangan Erikson mengenai perkembangan anak dari bayi hingga usia 12 tahun, konsep Erikson dijadikan oleh penulis kerangka pemikiran (framework) dalam teologi pengasuhan anak dalam keluarga. Erikson (Cremes, 1989; Newman \& Newman, 1987) tampaknya memahami bahwa harus ada yang bertumbuh dalam diri anak sebagai hasil pengasuhan yang baik dan benar di lingkungan sosialnya. Tugas perkembangan dari hasil perkembangan dan keutamaan yang muncul dalam setiap tahap secara ringkas dapat diuraikan sebagai berikut (Sumber: B.S.Sidjabat, 2008):

Tabel 1.2. Tahap Perkembangan Erik Erikson

\begin{tabular}{|c|c|c|c|c|}
\hline Tahap & Periode & $\begin{array}{c}\text { Tugas } \\
\text { Perkembangan }\end{array}$ & $\begin{array}{c}\text { Hasil } \\
\text { Perkembangan }\end{array}$ & Keutamaan \\
\hline 1 & $\begin{array}{c}\text { Bayi } \\
(0-2 \text { th })\end{array}$ & $\begin{array}{l}\text { 1. Keterikatan sosial } \\
\text { 2. Pematangan fungsi indra- } \\
\text { motorik } \\
\text { 3. Kecerdasan senso- } \\
\text { motorik dan kausalitas } \\
\text { primitif } \\
\text { 4. Permanensi objek } \\
\text { 5. Perkembangan emosi }\end{array}$ & $\begin{array}{l}\text { Kepercayaan dasar } \\
\text { (Trust) versus } \\
\text { Ketidakpercayaan } \\
\text { (Mistrust) }\end{array}$ & $\begin{array}{c}\text { Harapan } \\
\text { (Hope) }\end{array}$ \\
\hline 2 & $\begin{array}{l}\text { Kanak- } \\
\text { Kanak } \\
(2-4 \text { th) }\end{array}$ & $\begin{array}{l}\text { 1. Perluasan daya gerak } \\
\text { 2. Permainan dan fantasi } \\
\text { 3. Pengembangan bahasa } \\
\text { 4. Pengendalian diri (Self- } \\
\text { control) }\end{array}$ & $\begin{array}{c}\text { Kemandirian } \\
\text { (autonomy) versus } \\
\text { Rasa malu dan } \\
\text { Ragu-ragu (Shame } \\
\text { and Doubt) }\end{array}$ & $\begin{array}{c}\text { Prakarsa/Keh } \\
\text { endak (Will) }\end{array}$ \\
\hline 3 & $\begin{array}{l}\text { Pra- } \\
\text { Sekolah } \\
\text { (4-6 th) }\end{array}$ & $\begin{array}{l}\text { 1. Identifikasi peran seks } \\
\text { 2. Perkembangan awal } \\
\text { moral } \\
\text { 3. Bermain dalam } \\
\text { kelompok } \\
\text { 4. Perkembangan harga diri }\end{array}$ & $\begin{array}{c}\text { Inisiatif (Initiative) } \\
\text { versus Rasa } \\
\text { Bersalah (Guilt) }\end{array}$ & $\begin{array}{l}\text { Tujuan } \\
\text { (Purpose) }\end{array}$ \\
\hline 4 & $\begin{array}{l}\text { Anak SD } \\
\text { (6-12 th) }\end{array}$ & $\begin{array}{l}\text { 1. Persahabatan } \\
\text { (Friendship) } \\
\text { 2. Penilaian Diri (Self- }\end{array}$ & $\begin{array}{l}\text { Ketekunan } \\
\text { (Industry) versus } \\
\text { Rendah Diri }\end{array}$ & $\begin{array}{l}\text { Kemampuan } \\
\text { (Competence }\end{array}$ \\
\hline
\end{tabular}




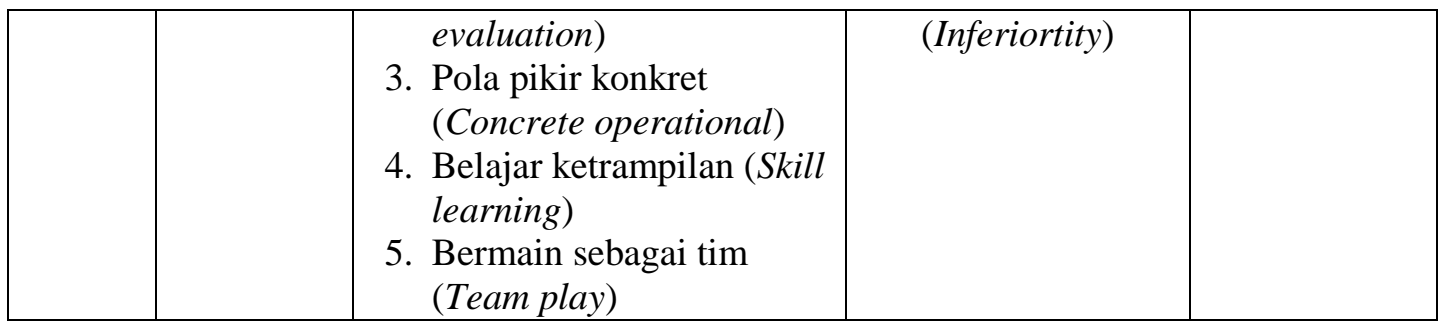

Memahami perkembangan dan kebutuhan anak sangat penting, karena kebutuhan yang tidak terpenuhi sesuai dengan tahap perkembangan anak akan berpengaruh kepada tahap perkembangan anak selanjutnya. Misalnya, seorang anak yang mengalami penolakan ketika berada di dalam kandungan akan mengalami gangguan / kelainan pada masa dewasa (Hak. 11:1-11). Dalam hal ini, orangtua diharapkan untuk memahami berbagai kebutuhan tersebut agar anak dapat bertumbuh sebagai pribadi yang sehat. Dengan demikian, mereka dapat memandang anak sebagaimana Tuhan Yesus memandang anak (Mat. 18:1-4). Dengan kata lain, dengan memahami tahap-tahap perkembangan di atas, diharapkan orang tua yang berperan sebagai guru dapat melakukan pengajaran dan pembinaan kerohanian anak supaya karakter dan perkembangan anak bertumbuh dengan baik sesuai dengan tahap-tahap perkembangan usianya.

\section{Memahami Generasi Orang Tua dan Generasi Anak Kita}

Lie mengemukakan bahwa setiap bangsa mempunyai pembagian generasi tersendiri yang biasanya dipengaruhi oleh karakteristik perjalanan sejarah bangsanya, misalnya di Amerika dikenal istilah-istilah builders (1930-1945), baby boomers (19561964), busters (1965-1981) dan the millennium generations (1982-2000). Berikut adalah penjabaran empat generasi tersebut (Sumber: Lie, 2017);

Tabel 1.3. Perbedaan Antar Generasi

\begin{tabular}{|c|c|c|c|}
\hline $\begin{array}{c}\text { Generasi X } \\
(1960-1980)\end{array}$ & $\begin{array}{l}\text { Generasi Y } \\
(1980-2000)\end{array}$ & $\begin{array}{c}\text { Generasi Z } \\
(1995-2010)\end{array}$ & $\begin{array}{c}\text { Generasi Alpha ( }(\boldsymbol{\alpha}) \\
(2010-2025)\end{array}$ \\
\hline $\begin{array}{l}\text { Dilahirkan di } \\
\text { tengah dunia yang } \\
\text { mendemonstrasikan } \\
\text { tren perceraian dan } \\
\text { ekonomi yang tidak } \\
\text { pasti. }\end{array}$ & $\begin{array}{l}\text { Dilahirkan di } \\
\text { konteks dunia yang } \\
\text { diwarnai dengan } \\
\text { bertambahnya } \\
\text { konflik antar } \\
\text { Negara dan antar } \\
\text { komunitas. }\end{array}$ & $\begin{array}{l}\text { Dilahirkan dalam } \\
\text { dunia yang sedang } \\
\text { menghadapi } \\
\text { beragam tantangan } \\
\text { seperti terorisme } \\
\text { dan keprihatinan } \\
\text { terhadap } \\
\text { lingkungan. }\end{array}$ & $\begin{array}{l}\text { Dilahirkan dalam } \\
\text { dunia yang baru saja } \\
\text { muncul dengan } \\
\text { perlambatan } \\
\text { ekonomi di mana- } \\
\text { mana. }\end{array}$ \\
\hline $\begin{array}{l}\text { Menikmati } \\
\text { pelbagai fasilitas, } \\
\text { popularitas budaya } \\
\text { disko, hip hop dan } \\
\text { kemajuan } \\
\text { teknologi. } \\
\text { Misalnya, TV } \\
\text { kabel, game video, }\end{array}$ & $\begin{array}{l}\text { Menyaksikan } \\
\text { munculnya } \\
\text { teknologi digital, } \\
\text { seperti komunikasi } \\
\text { secara instan via } \\
\text { SMS misalnya }\end{array}$ & $\begin{array}{l}\text { Menjadi saksi } \\
\text { penyebarluasan } \\
\text { dalam pemakaian } \\
\text { gadget dan } \\
\text { teknologi digital } \\
\text { seperti internet dan } \\
\text { situs-situs media } \\
\text { sosial. }\end{array}$ & $\begin{array}{l}\text { Diharapkan } \\
\text { memiliki } \\
\text { kompetensi yang } \\
\text { lebih cerdas dalam } \\
\text { teknologi, lebih } \\
\text { berpendidikan } \\
\text { tinggi, dan lebih } \\
\text { mengejar kemajuan }\end{array}$ \\
\hline
\end{tabular}




\begin{tabular}{|c|c|c|c|}
\hline dan lainnya. & & & materialistik \\
\hline $\begin{array}{l}\text { Eksis dalam } \\
\text { masyarakat yang } \\
\text { bersifat } \\
\text { individualistis } \\
\text { (egois) dan } \\
\text { bersikap ragu } \\
\text { terhadap wewenang } \\
\text { atau otoritas }\end{array}$ & $\begin{array}{l}\text { Hidup di tengah } \\
\text { masyarakat yang } \\
\text { karakteristiknya } \\
\text { optimis, nyaman } \\
\text { dengan teknologi, } \\
\text { lebih perhatikan } \\
\text { gaya, dan loyal } \\
\text { terhadap merk } \\
\text { tertentu. }\end{array}$ & $\begin{array}{l}\text { Eksis dalam } \\
\text { masyarakat yang } \\
\text { cerdas teknologi, } \\
\text { terkoneksi secara } \\
\text { global (dalam } \\
\text { dunia maya), lebih } \\
\text { bersifat fleksibel } \\
\text { dan lebih pandai, } \\
\text { juga bersikap } \\
\text { toleran terhadap } \\
\text { budaya-budaya } \\
\text { yang berbeda- } \\
\text { beda. }\end{array}$ & \\
\hline
\end{tabular}

Orang tua diharapkan dapat mengenali generasi mereka dan anak-anak mereka agar dengan mudah mengerti bagaimana mengasuh anak-anak dengan baik tentu dengan pola baru. Pengenalan yang benar akan generasi yang dididik turut menentukan dalam menghasilkan anak-anak yang unggul.

\section{Mengenali Tantangan Masa Kini}

Sidjabat dalam jurnal ilmiah Pengarah, Sekolah Tinggi Alkitab Tiranus mengemukakan bahwa sekarang dengan kemajuan cyber space segala simbol (non human) memberi informasi dan mengajari bahkan seperti mengendalikan pikiran, perasaan dan sikap manusia. Informasi apapun (pengetahuan, teknologi, agama, keyakinan, seks, kebudayaan, politik, ekonomi) menerobos ke arah mana manusia (mungkin spesies) dapat dijumpainya. Jadi, sesuatu yang non human menentukan kehidupan manusia (human) di dunia ini. Kedaulatan manusia tergeser: manusia sepertinya sedang "dikejar-kejar" oleh ragam informasi, pekerjaan, nilai-nilai, juga "mahluk-mahluk halus" yang menuntut responnya (waktu, energi, perhatian). Pikiran, hati dan emosi si pengguna gadget diatur oleh beragam program di dalamnya (Sidjabat, 2015). Semua program gadget tidak semuanya baik untuk anak-anak kita, ada juga yang belum waktunya dilihat oleh anak-anak, seperti korban kecelakaan lalu lintas, pembunuhan, pornografi, dan sebagainya. Orang tua harus tahu bahwa gadget yang dipegang atau dipinjamkan kepada anak adalah barang mainan yang sangat berbahaya meskipun di dalamnya ada video yang mendidik, namun anak-anak yang masih kecil belum dapat memilah-milah yang mana yang baik utuk mereka dan yang mana yang tidak. Anak-anak menganggap semua yang ada di Youtube, Instagram, Tiktok, Snack Video adalah baik. Orang tua harus tahu bahwa sebagian besar konten dalam gadget adalah "racun" bagi anak-anak. Seandainya orang tua memberikan gadget kepada anakanak mereka, maka harus ada pendampingan orang tua, jangan membiarkan anak-anak bermain sendiri dengan gadget itu.

Tantangan pada abad ke-21 ini banyak generasi muda menjauhkan diri dari Tuhan dan gereja-Nya karena bermain gadget baik di rumah maupun di gereja. Anakanak muda tidak lagi membawa Alkitab (buku) ke dalam gereja melainkan gadget, sehingga ketika firman Allah disampaikan, mereka membuka gadget dan melihat pesan whatshapp, Instagram, Facebook, Tiktok, Snack Video dan lain-lain. Firman Tuhan 
yang disampaikan tidak diperhatikan dan tidak dilakukan. Hal senada dikemukakan oleh Mayenti (2018:209), bahkan pemuda-pemudi saat ini seolah-olah mengeluh ketika gadget, smartphone tidak ada pada genggaman tangan mereka, ini mengindikasikan bahwa ketergantungan terhadap gadget, smartphone itu telah mulai hadir, dan ini adalah salah satu terobosan baru pada era industri 4.0, maupun 5.0.

\section{Mengantisipasi Kemajuan Zaman}

Saat ini kita sedang berada pada era society 4.0 dan sedang menuju kepada era 5.0 yang memungkinkan kita akan terhubung ke seluruh dunia. Dengan adanya era digital yang semakin canggih, manusia akan semakin dapat melakukan segala sesuatu dengan mudah dan hemat. Hal ini dapat menimbulkan masalah antara orang tua dengan keturunan mereka yang sehari-harinya berkecimpung dengan teknologi canggih yang dipelajari dari guru di sekolahnya dan teman-teman di lingkungan sosialnya. Teknologi yang semakin canggih ini dapat menciptakan jurang pemisah antara kehidupan anak dengan gereja bahkan sangat mungkin meninggalkan iman mereka karena menganggap teknologi sebagai "tuhan" yang harus dipenuhi tuntutannya. Manusia dapat menjadi "budak" teknologi. Mereka bisa menggunakan gadget selama berjam-jam dan hampir tidak memiliki waktu untuk berdoa, bernyanyi dan membaca Alkitab. Gadget mempunyai pelbagai perangkat, fitur dan aplikasi menarik, variatif, berinteraksi dan fleksibel sehingga menambah minat bagi segala umur, apakah itu dari kelompok lanjut usia (lansia), paruh baya, dewasa awal, pemuda / pemudi, remaja, secara khusus anakanak. Sejatinya, gadget memiliki pelbagai manfaat dalam seantero hidup manusia jika dipergunakan dengan baik, benar, bertanggung jawab dan tepat (positif), namun gadget juga memberikan pengaruh buruk (negatif) bagi manusia khususnya bagi perkembangan anak jika dipakai tanpa pengawasan, pembatasan dan pengarahan dari setiap orang tua (Mayenti: 2018:208).

\section{Menata Ulang Pendidikan Kristen Kepada Generasi Muda}

Orang tua disebut berhasil ialah apabila mereka telah menyiapkan anak-anaknya menjadi generasi penerus yang baik, baik penerus iman, karakter dan keluarga. Mengapa disebut demikian? Karena inilah yang menjadi kunci kemajuan dimana generasi muda lebih baik daripada generasi sebelumnya. Dalam bukunya Sidabat (2011) yang berjudul Membangun Manusia Unggul mengemukakan bahwa menyiapkan anak-anak dalam keluarga dibutuhkan pola yang bisa berubah-ubah sesuai dengan perkembangan zaman. Sama seperti seorang desainer pakaian, dia harus bersedia mengubah pola desain sesuai dengan perkembangan model fashion yang diminati masyarakat atau sesuai dengan pesanan konsumen. Jika dia terus menggunakan pola yang sama dari tahun ke tahun, maka kemungkinan besar jualan pakaiannya tidak akan laku karena semua orang belanja pakaian mengikuti mode terbaru bukan mode terlama. Orang tua sudah terbiasa mendidik anak-anak dengan pola asuh yang mereka miliki, entah anak suka atau tidak suka, pola itu akan tetap dilakukan. Tetapi bagaimana seandainya anak-anak yang dididik tidak mau dan cara mereka menolak ialah dengan cara berperilaku sesuai model zaman ini? Jika demikian, timbullah masalah besar dalam menyiapkan generasi baru dalam keluarga. Orang tua adalah pendidik dalam keluarga dan mereka juga turut menjadi penentu keberhasilan anak-anak mereka.

Maka hal yang sangat penting dipahami oleh orang tua berkaitan dengan pola asuh ialah: pertama, spiritualitas orang tua sebagai pendidik utama dan pertama dalam keluarga, Kedua, kemampuan membaca zaman atau memahami perkembangan zaman 
yang di dalamnya ada teknologi, sosial, dan pola hidup generasi muda. Ketiga, sejauhmana kemampuan orang tua dalam mendidik anak-anak, apakah orang tua perlu didampingi atau tidak. Keempat, pentingnya memahami latarbelakang pendidikan orang tua karena tidak semua orang tua lulus sarjana (Sidjabat, 2008:3-9).

Dalam menata ulang pendidikan Kristen kepada generasi muda (pengasuhan Kristiani), maka ada empat aspek yang harus diperhatikan dengan seksama oleh orang tua Kristen, antara lain;

\section{Orang Tua dan Gereja Bekerjasama Mendidik Generasi Muda}

Orang tua adalah bagian dari gereja. Gereja terdiri dari orang tua dan anak-anak. Jika ingin berhasil dalam pendidikan keluarga, maka keluarga atau orang tua harus bekerja sama dengan gereja, artinya tidak bisa berjalan sendiri-sendiri, keduanya harus berjalan bersamaan, sehingga anak-anak dalam keluarga memperoleh pendidikan rohani dari dua lembaga resmi itu. Jika ajaran di gereja tidak sama dengan ajaran orang tua, ada kemungkinan terjadi mis komunikasi. Orang tua belajar di gereja untuk kemudian mereka mengajar anak di rumah. Selain mengaharapkan anak menjadi pelaku firman Tuhan, maka orang tua terlebih dahulu meneladankan kepada anak-anak, sehingga anak-anak akan patuh kepada ajaran dan nasihat firman Tuhan, demikian sebaliknya.

Gereja bertanggung jawab untuk menolong, memperlengkapi orang dewasa / orang tua menemukan Allah yang aktif, berprakarsa dalam setiap peristiwa kehidupan manusia, percaya dan mempercayakan hidup mereka seutuhnya dalam tarafnya yang paling dalam untuk alasan ini, dan untuk merayakan dengan sukacita perbuatan Allah yang sempurna dalam Tuhan Yesus Kristus dan berlangsung terus melalui Allah Roh Kudus (Case, 1966:205). Apabila orang dewasa / orang tua Kristen sehat melalui pendidikan / pembinaan yang dilaksanakan oleh gereja maka tendensinya anak-anak akan terperhatikan. Mendidik orang dewasa sudah di dalamnya sedang mendidik anakanak.

\section{Menerapkan Prinsip Pembelajaran Yang Mudah Diikuti}

Seringkali pengajaran orang tua sulit dimengerti oleh anak-anak. Daya tangkap anak-anak ditentukan oleh faktor perkembangan mereka. Ada kalanya bahasa orang tua terlalu tinggi sehingga anak-anak tidak dapat menangkap pesan yang disampaikan oleh anak-anak. Orang tua juga perlu mendengarkan cerita (curhatan) anak-anak mereka agar orang tua tahu apa yang sedang dipikirkan oleh anak-anak mereka (Bandingkan Daeli dan Nainggolan, 2020). Anak-anak sekolah Minggu tidak tertarik dengan gurunya karena guru hanya menceramahi mereka. Demikian juga remaja dan pemuda di gereja, mereka semakin meninggalkan persekutuan di gereja dan berfokus kepada gadget mereka.

Lie seorang pakar pendidikan Kristen yang mempelajari buku Kinnaman dan kemudian direfleksikan dengan pengalaman pribadinya, beliau menyampaikan enam alasan mengapa generasi muda Kristen meninggalkan gereja: Pertama, cara gereja dalam menyelenggarakan pelayanannya yang telah usang dimakan zaman yang berbeda; kedua, gereja telah kehilangan daya tarik dalam kerutinannya; ketiga, generasi muda tidak menyukai sosok "talking heads" (pembicara yang hanya bicara dengan metode ceramah satu arah (one-way-lecture/preaching); keempat, para rohaniawan hanya berkhotbah di isu seputar teologi yang tidak terintegrasi dengan ilmu-ilmu pengetahuan lainnya (tidak melakukan pendekatan inter-disipliner/cross-disciliner); kelima, para aktivis gereja sangat tertutup dengan keterlibatan orang-orang tertentu saja alias $4 \mathrm{~L}$ 
("Lu Lagi, Lu Lagi”) sehingga kehadiran dan potensi kaum muda yang lain tidak terpakai; keenam, gereja memang melakukan pemuridan, tetapi dengan sistem massal (mas-production) bukan kelompok kecil, sehingga tidak menyentuh kebutuhan di tingkat personal (tailor-made). (Lie, 2017; Kinnaman 2011). Orang tua dan gereja perlu duduk bersama untuk memikirkan pendidikan generasi muda. Gereja diharapkan bisa mengakomodir usulan orang tua agar tercipta sebuah pendidikan rohani yang signifikan.

\section{Mereformasi Sistem Pembelajaran}

Sebagai mantan seorang anak dalam keluarga, penulis melihat dan merasakan bagaimana orang tua mendidik kami di rumah. Biasanya orang tua kami memberikan ceramah monolog dan kami hanya mendengar dan patuh. Kami tidak bisa mengajukan pertanyaan terkait ajaran orang tua itu. Pengajaran yang sering diulang setiap hari ialah menghormati orang tua (Titah ke-5 dari sepuluh Hukum Taurat). Bagaimana cara menghormati orang tua kami tidak tahu waktu itu, yang penting melakukan semua yang disuruh oleh orang tua, anak yang membantah akan kena sangsi. Banyak orang tua menganggap cara mereka mendidik anak-anak tidak pernah salah. Di sekolah Minggu di gereja juga demikian, guru mengajar dan murid diam mendengarkan. Itu sebabnya perlu mereformasi sistem pendidikan dalam keluarga dan gereja agar pendidikan keluarga dan gereja semakin menjawab tantangan zaman. Jangan sampai anak-anak kita menghindari pendidikan keluarga dan gereja.

Lie memberikan prinsip-prinsip edukatif yang diharapkan dapat mereformasi sistem pembelajaran yang penulis ringkas demikian, pertama, sistem pembelajaran conventional yang menyetujui bahwa peran pendidik yang utama adalah pemberi informasi (transmitter pengetahuan) perlu direformasi ke dalam sistem pembelajaran unconventional di mana pendidik lebih berperan sebagai pemberi arah dan pemberi alternatif solusi. Informasi bukan sama sekali tidak dibutuhkan generasi muda, tapi mereka lebih butuh arahan dan alternative solution, yang tidak mereka dapatkan melalui teknologi informasi. Kedua, Sistem pembelajaran conventional yang menyetujui pola pembinaan yang indoktriner dan otoriter perlu direformasi ke dalam sistem pembelajaran unconventional di mana pendidik lebih menerapkan pola pembinaan yang discerning untuk membangun fondasi iman yang kokoh. Ketiga, Sistem pembelajaran conventional yang menerapkan proses belajar-mengajar yang pasif di mana peserta didik hanya jadi pendengar dan penonton, perlu direformasi ke dalam sistem pembelajaran unconventional yang menerapkan proses belajar-mengajar yang aktif dan parsipatori di mana peserta didik menjadi terlibat (engaged) sebagai contributor dan pemain. Mereka akan sangat senang jika dilibatkan untuk tanya-jawab, berdiskusi, berargumentasi, bahkan berdebat untuk menjernihkan ide sampai menemukan kebenaran Kekristenan. Keempat, Sistem pembelajaran conventional yang menerapkan sistem pemuridan massal, perlu direformasi ke dalam sistem pembelajaran unconventional yang menerapkan sistem pemuridan dalam kelompok kecil. Generasi muda tidak suka dengan sistem pemuridan massal yang hampa hubungan yang personal. Mereka menyukai komunitas kelompok kecil yang memungkinkan terbangunnya hubungan antar-pribadi yang maya. Memang melalui media sosial, mereka dapat berhubungan dengan siapa saja, tetapi hubungan seperti itu tidak akan memenuhi kebutuhan hubungan yang riil dan mendalam. Kelima, Sistem pembelajaran conventional yang mana para pembina kaum muda terbiasa berperan sebagai pembuat murid dari para remaja (pengganti orang tua), perlu direformasi ke dalam sistem pembelajaran unconventional yang mengembalikan peran pembuat murid dari pembina 
kaum muda kepada orang tua di mana ayah sebagai pembuat murid bagi anak lakilakinya dan ibu sebagai pembuat murid bagi anak perempuannya. Orang tua adalah pembuat murid yang paling efektif. Hal ini dibuktikan dalam tulisan yang dimuat dalam artikel yang berjudul The secret of faith after high school? Parents! Disebutkan bahwa orang muda yang sering mendengar sharing pengalaman iman dari orang tuanya, pada umumnya mereka jauh lebih kuat dalam menghadapi tantangan iman. Ada keluargakeluarga tertentu yang membangun kebiasaan berdoa bersama keluarga. Saat berdoa, iman orang tua didemonstrasikan di hadapan anak-anak. Kehidupan iman orang tua terbukti paling berpengaruh bagi perkembangan iman anak (Lie, 2017).

Purba mengemukakan tentang orang tua sebagai pengarah, maka orang tua harus mampu membangun hubungan akrab dengan anak-anaknya. Hubungan yang paling baik antara orang tua dengan anak ialah hubungan persahabatan karena anak-anak membutuhkan sahabat dengan orang dewasa. Persahabatan orang tua dengan anak sangatlah penting. Persahabatan yang akrab antara orang tua dengan anak dapat membangun trust dan spiritualitas anak akan dibangun dengan baik. Kegiatan persahabatan itu diwarnai dengan persekutuan keluarga, doa bersama atau pribadi, sesi 'curhat' dan mengutarakan hal-hal yang sangat pribadi bagi anak. Hubungan antara orang tua dengan anak dapat disebut sebagai hubungan horizontal dan hubungan keluarga dengan Tuhan disebut hubungan vertikal dimana orang tua juga adalah wakil Allah. Orang tua bertanggung jawab membawa anak-anak dalam persekutuan dengan Tuhan sejak mereka masih bayi sampai dewasa (Purba, 2021).

Dalam Mengasuh anak dua puluh lima hal di bawah ini harus menjadi perhatian; (Wijanarko, 19-21);

Tabel.1.4. Perilaku Orang Tua Dan Respon Anak

\begin{tabular}{|c|c|c|}
\hline No. & Perilaku orang tua & Reaksi/Respon anak \\
\hline 1. & Tidak menepati janji terhadap anak & Hati terluka / luka batin \\
\hline 2. & Tidak mengaku salah terhadap anak & $\begin{array}{c}\text { Kehilangan kepercayaan terhadap } \\
\text { otoritas orang tua }\end{array}$ \\
\hline 3. & $\begin{array}{c}\text { Menolak untuk meminta maaf kepada } \\
\text { anak }\end{array}$ & $\begin{array}{c}\text { Bereaksi terhadap kesombongan orang } \\
\text { tua, Kehilangan figur model / teladan }\end{array}$ \\
\hline 4. & $\begin{array}{c}\text { Tidak memiliki urutan prioritas dalam } \\
\text { kehidupan berkeluarga }\end{array}$ & $\begin{array}{c}\text { Merasa dan memandang ayah terlalu } \\
\text { sibuk buat anaknya, anak mengikuti } \\
\text { jadi serabutan }\end{array}$ \\
\hline 5. & Mendisiplin anak terlalu keras & Hancur hati \\
\hline 6. & Mendisiplin dengan kemarahan & $\begin{array}{c}\text { Memendam benih kekecewaan dan } \\
\text { akar pahit }\end{array}$ \\
\hline 7. & $\begin{array}{c}\text { Mendelegasikan pendidikan kepada } \\
\text { Sekolah Minggu, gereja, sekolah dan } \\
\text { masyarakat }\end{array}$ & $\begin{array}{c}\text { Tidak menghargai orang tua sebagai } \\
\text { figur/guru }\end{array}$ \\
\hline 8. & $\begin{array}{c}\text { Memberi kebebasan berlebih terhadap } \\
\text { anak }\end{array}$ & $\begin{array}{c}\text { Melihat kebebasan sebagai penolakan } \\
\text { dan ketidakperhatian orang tua }\end{array}$ \\
\hline 9. & $\begin{array}{c}\text { Tidak menghormati orang tua (bdk. } \\
\text { Kel. 17:1-17) }\end{array}$ & $\begin{array}{c}\text { Anak tidak menghormati kakek dan } \\
\text { neneknya }\end{array}$ \\
\hline
\end{tabular}




\begin{tabular}{|c|c|c|}
\hline 10. & $\begin{array}{l}\text { Mengirim orang tua ke panti jompo } \\
\text { ketika sudah lanjut usia }\end{array}$ & $\begin{array}{c}\text { Anak akan menolak orang-orang yang } \\
\text { lebih tua/kurang ajar }\end{array}$ \\
\hline 11. & $\begin{array}{c}\text { Suami tidak mengasihi istri sesuai } \\
\text { dengan janji pernikahan }\end{array}$ & $\begin{array}{c}\text { Anak melawan ibunya, anak } \\
\text { kecewa/kepahitan dengan ayahnya }\end{array}$ \\
\hline 12. & Istri memberontak terhadap suami & $\begin{array}{c}\text { Anak melawan ayahnya, anak } \\
\text { kehilangan figur, anak } \\
\text { kecewa/kepahitan dengan ibunya }\end{array}$ \\
\hline 13. & $\begin{array}{l}\text { Menolak firman Tuhan sebagai } \\
\text { pedoman hidup berkeluarga }\end{array}$ & $\begin{array}{c}\text { Hal yang sama dilakukan anak, tidak } \\
\text { bisa takut akan Tuhan, cenderung } \\
\text { nakal, susah dididik }\end{array}$ \\
\hline 14. & $\begin{array}{c}\text { Selalu memuji anak lain atau } \\
\text { membandingkan anak sendiri dengan } \\
\text { orang lain }\end{array}$ & Merasa tertolak, minder, rendah diri \\
\hline 15. & Terlalu diam / apatis terhadap anak & $\begin{array}{c}\text { Mencari penerimaan dan penghargaan } \\
\text { diri dari teman sebaya }\end{array}$ \\
\hline 16. & $\begin{array}{l}\text { Tidak konsisten standar kehidupan di } \\
\text { tengah keluarga }\end{array}$ & Menjauh dari orang tua \\
\hline 17. & $\begin{array}{c}\text { Menyeleweng dalam pernikahan / } \\
\text { selingkuh dan sejenisnya }\end{array}$ & $\begin{array}{l}\text { Kebencian, kehilangan figur (gambar } \\
\text { orang tua), menikah untuk keluar dari } \\
\text { rumah }\end{array}$ \\
\hline 18. & $\begin{array}{c}\text { Selalu mengingat kesalahan atau sukar } \\
\text { mengampuni }\end{array}$ & $\begin{array}{l}\text { Anak justru akan melakukan lagi, anak } \\
\text { tidak belajar arti pengampunan, anak } \\
\text { merasa ditolak secara pribadi, anak } \\
\text { merasa kesepian di tengah keluarga }\end{array}$ \\
\hline 19. & $\begin{array}{l}\text { Tidak memiliki kesaksian hidup yang } \\
\text { baik }\end{array}$ & $\begin{array}{l}\text { Mengikuti norma dan etika dunia } \\
\text { bukan etika Kristen }\end{array}$ \\
\hline 20. & $\begin{array}{l}\text { Tidak memberikan pendidikan rohani } \\
\text { (tidak ada mezbah doa), materialis, } \\
\text { pelit (kikir) }\end{array}$ & $\begin{array}{l}\text { Anak tumbuh duniawi dan mengikuti } \\
\text { kedagingannya }\end{array}$ \\
\hline 21. & $\begin{array}{l}\text { Mengutamakan pekerjaan daripada } \\
\text { keluarga }\end{array}$ & $\begin{array}{l}\text { Membangun nilai hidup atas dasar hal- } \\
\text { hal yang fana. }\end{array}$ \\
\hline 22. & nncam anak & Membenci, memberontak \\
\hline 23. & Menekan, menyalahkan anak & $\begin{array}{c}\text { Menekan dan menyalahkan adik- } \\
\text { adiknya sebagai } \\
\text { penyaluran/pelampiasan ketika } \\
\text { dimarahi orangtua }\end{array}$ \\
\hline 24. & Memanjakan anak secara berlebihan & $=$ Liar / bebas \\
\hline 25 . & Tidak memperhatikan kondisi anak & $\begin{array}{l}\text { Mencari perhatian dengan nakal, usil, } \\
\text { aktif, dan berbagai kegiatan ekstrim }\end{array}$ \\
\hline
\end{tabular}

Dari dua puluh lima (25) perilaku orangtua dalam membesarkan anak dan yang menghasilkan respons anak di atas, mengajarkan agar orang tua berhati-hati, bijak dalam mempertimbangkan tipe pola asuh terhadap anak. Untuk menghasilkan anak yang unggul diperlukan ajaran dan teladan hidup yang berorientasi kepada firman Tuhan. Perilaku anak adalah buah dari pengasuhan yang diterapkan oleh orang tua di rumah. Selanjutnya, dua puluh lima (25) perilaku orang tua dan respons anak di atas 
menjadi peringatan kepada orang tua di masa kini dan mendatang agar tidak mendemonstrasikannya dalam kehidupan berkeluarga. Seyogianya keluarga inti yang terdiri dari ayah, ibu dan anak hidup dalam rasa takut akan Tuhan, hidup sesuai dengan prinsip Alkitab sehingga mampu melaksanakan peran, fungsi dan tanggung jawabnya dengan baik, sesuai dengan kehendak Allah. Diyakini akan menghasilkan keluarga yang harmonis dan memuliakan Tuhan.

\section{Rancang Bangun Pendidikan Rohani Anak Oleh Orang Tua Menghadapi Kemajuan (tren) Zaman}

Penulis mengusulkan sepuluh (10) rancang bangun pendidikan orang tua terhadap anak di rumah, antara lain:

Pertama, orangtua harus mengasuh anak dengan baik. Melalui pengasuhan orangtua penting untuk membantu anak dalam pengembangan iman, moral dan dimensi lain dari anak yang sehat. Pemeliharaan terbaik yang didapatkan dari orangtua akan menghasilkan kepribadian, spritualitas, sosial, emosi, moral yang positif (basic trust).

Kedua, orang tua perlu menyampaikan betapa pentingnya menyadari bahwa anak-anak membutuhkan Juru selamat untuk menerima pengampunan-Nya karena mereka adalah orang berdosa. Tuhan mau supaya setiap orang tidak bercacat cela pada waktu kedatangan-Nya. Rasul Paulus mengatakan bahwa setiap orang Kristen harus selalu berfokus pada tujuan hidup (Fil. 2:15-16). Mengajar dan membimbing anak-anak untuk mengalami perjumpaan dengan Tuhan Yesus Kristus (untuk mempertegas pengakuan). Kemungkinan anak-anak kita sudah sudah terhisab ke dalam pengaruh gadget itu. Anak-anak perlu dibimbing untuk terus percaya sungguh-sungguh dan mengalami pertumbuhan iman. Tuhan Yesuslah sumber kehidupan orang percaya. Yesuslah jalan dan kebenaran dan kehidupan, di luar Yesus tidak ada keselamatan (Yoh.14:6 dan Kisah 4:12). Pengasuhan orangtua terhadap anak yang tepat harus dimulai dengan perjumpaan secara pribadi dengan Yesus (Sidjabat, 2008:3-9).

Ketiga, membimbing anak-anak untuk dipimpin oleh Roh Kudus supaya mereka mengalami perubahan hidup, dikendalikan dan dipimpin oleh-Nya. Pimpinan Roh Kudus akan memampukan anak-anak untuk menghasilkan buah-buah Roh Kudus (Gal. 5:22-23) dan menghindari keinginan daging (Gal. 5:19-21).

Keempat, anak-anak dibimbing dan dituntun untuk membaca Alkitab bahkan menghafalkannya agar pengaruh-pengaruh gadget dapat dikonfrontir oleh kebenaran firman Tuhan. Roh Kudus memakai firman-Nya siang dan malam dibacakan dalam keluarga yang untuk menumbuhkan iman dan merobohkan sifat-sifat buruk yang ditaburkan oleh dunia ini melalui gadget. Pendidikan iman dan moral dapat dilakukan dengan mengajarkan firman Tuhan dengan efektif dan kreatif (bdk. Ul. 6:4-9; 2 Tim. $3: 16)$.

Kelima, anak-anak dimuridkan oleh ayah dengan putranya dan oleh ibu dengan putrinya setiap sekali seminggu agar mereka bertumbuh di dalam iman dan firman.

Keenam, orang tua mengasuh anak melalui keteladanan (Sidjabat, 2008:3-9). Orangtua harus menjadi contoh / teladan / model hidup bagi anak-anak. Pengajaran mereka harus selaras dengan perilaku hidup sehari-hari. Sebab, anak cenderung belajar melalui contoh nyata / peniruan.

Ketujuh, orang tua mengajak anak untuk bercakap-cakap tentang imannya kepada Tuhan Yesus Kristus. Mungkin yang orang tua imani berbeda dengan yang diimani anak-anak. Mengapa bisa demikian? Karena anak-anak kita tidak mudah mencerna pengajaran guru di Sekolah Minggu dan guru agama di sekolah. Beriman itu 
abstrak dan sangat sulit dijelaskan. Mungkin orang dewasa juga sulit menjelaskan hidup beriman itu, apalagi anak-anak masa kini? Keimanan sangat perlu dipercakapkan antara orang tua dan anak-anak.

Kedelapan, dibutuhkan kehidupan doa dalam keluarga. Anak-anak akan rajin berdoa kepada Tuhan apabila mereka melihat orang tuanya rajin berdoa. Semua pergumulan hidup dipanjatkan kepada Tuhan bersama anak-anak walaupun mereka sering bosan dengan doa yang agak lama. Tetapi apabila dibiasakan berdoa bersama keluarga, maka anak-anak juga akan mengikutinya.

Kesembilan, mendidik anak-anak melakukan firman Tuhan mulai dari hal yang sederhana seperti membantu pekerjaan orang tua di rumah, membantu anak yatim piatu di panti asuhan, mendoakan temannya yang sakit dan sebagainya. Anak perlu diajar hidup berbelaskasihan atau peduli (care) kepada orang lain. Orang tua perlu membimbing anak-anak menabung dari sisa jajan mereka untuk kemudian diberikan kepada orang yang sangat membutuhkan.

Kesepuluh, anak-anak perlu dievaluasi oleh orang tua. Mengevaluasi tingkah laku mereka, percakapan mereka, pelajaran firman Tuhan, kehidupan doa dan sebagainya. Kegiatan evaluasi ini bisa dilakukan sekali seminggu atau sekali dalam dua minggu. Mengapa anak perlu dievaluasi? Agar mereka tahu di mana yang kurang dan apa saja kelebihan mereka, sehingga anak-anak akan tumbuh dalam perhatian dan kasih sayang orang tua. Kebiasaan orang tua yang merugikan anak ialah: menegur anak pada waktu dia sedang melakukan kesalahan tetapi tidak atau lupa memuji ketika dia sedang berbuat yang benar/baik. Mungkin pada waktu orang tua mengevaluasi tingkah laku anak-anak, mereka juga akan menyampaikan teguran kepada orang tua. Mengapa mereka bersikap buruk? Ya mungkin karena meneladani orang tua? Jadi evaluasi sangat perlu dilakukan!

\section{SIMPULAN DAN SARAN}

Orangtua Kristen memiliki kedudukan, peran dan fungsi strategis dalam mengasuh anak agar tidak menjadi korban kemajuan zaman. Gaya hidup anak tentu mengikuti perkembangan zaman, namun yang harus diperhatikan dengan seksama oleh orangtua adalah agar anak tidak terjerumus dalam penggunaan smartphone / teknologi informasi yang semakin berubah dan berkembang. Pembatasan dan pengawasan penggunaan smartphone oleh orang tua Kristen patut dilakukan secara disiplin. Sejatinya, pola asuh yang didemonstrasikan oleh orangtua Kristen dalam menghadapi tantangan kemajuan zaman haruslah berpusat pada Alkitab, memperkenalkan anak dengan Tuhan Yesus sehingga ia beriman kepada-Nya. Dengan demikian, sang anak akan di tolong dan diperbaharui oleh Roh Kudus dalam pertumbuhan dan perkembangannya secara holistik. Mengingat tanggung jawab orangtua besar dalam mengasuh anak di zaman yang terus berubah dan berkembang, maka penting bagi orangtua untuk terus belajar dalam memahami tahap-tahap perkembangan anak, baik secara fisik, kognitif, sosial, moral, emosi, spritualitas dan lainnya, dan mengenali perbedaan generasi antara orangtua dan anak. Di samping itu, dalam pengasuhannya orangtua harus mendemonstrasikan keteladanan terhadap anak, karena anak bukan hanya belajar dari apa yang dikatakan oleh orang tua namun melalui apa yang dilihatnya. Akhirnya, untuk meneguhkan upaya orangtua Kristen dalam mengasuh anak menghadapi tantangan zaman, maka mereka dapat menjadikan gereja, sekolah dan masyarakat sebagai mitra. 
Untuk penelitian selanjutnya peneliti dapat melakukan penelitian dengan topik yang sama, namun dengan metode yang berbeda, misalnya menggunakan metode kuantitatif, metode kombinasi ataupun metode historis kritis terhadap teks tertentu dalam Alkitab yang membahas tentang pola asuh orangtua terhadap anak. Misalnya, meneliti relasi pola asuh orang tua Kristen dengan kualitas moral anak di gereja lokal tertentu di Manado, Sulawesi Utara; Pola asuh orang tua terhadap anak dengan pendekatan historis kritis berdasarkan Ulangan 6:4-9 dan lainnya.

Melalui penelitian ini diharapkan agar: Pertama, orangtua Kristen memiliki pola asuh yang berpadanan dengan Alkitab. Kedua, orangtua Kristen menjadi teladan bagi anak dalam proses pengasuhan. Ketiga, orangtua Kristen termotivasi untuk memperlengkapi diri dalam memahami tahap-tahap perkembangan anak (fisik, kognitif, sosial, emosi, moral, spritual). Keempat, orangtua Kristen mengerti kesenjangan antara generasi orang tua dengan generasi anak. Kelima, orangtua Kristen mengetahui arah dan tantangan zaman masa kini dan mendatang. Keenam, orangtua Kristen mampu mengantisipasi kemajuan (tren) zaman di bawah pimpinan Allah Tritunggal. Ketujuh, menerapkan rancang bangun pendidikan rohani anak oleh orang tua Kristen di rumah dalam menghadapi kemajuan zaman. Ketujuh, orang tua perlu mengajak anak untuk bercakap-cakap tentang imannya kepada Yesus. Kedelapan, orang tua perlu membangun kehidupan doa yang berkualitas dalam keluarga. Kesembilan, mendidik anak-anak melakukan firman Tuhan mulai dari hal yang sederhana sampai yang kompleks. Kesepuluh, orang tua perlu melakukan evaluasi terhadap pertumbuhan dan perkembangan anak, baik dalam dimensi iman, kognitif, emosi, sosial dan lainnya agar anak dapat bertumbuh dan berkembang secara utuh.

\section{DAFTAR PUSTAKA}

Case, William F. (1966). Adult Education in the Chuch. An Introduction to Christian Education (Nashville, New York: Abingdon Press.

Giok Lie, Tan (2017). Generasi ke Generasi. Bandung: Penerbit: PT. Visi Anugerah Indonesia.

Ismail, Andar. (2014). Selamat Menabur. Jakarta: BPK Gunung Mulia.

Lilik, Sriyanti (2014). Psikologi Anak: Mengenal Autis hingga Hiperaktif. Salatiga: STAIN Salatiga Press.

Nainggolan, JM. (2008). Strategi Pendidikan Agama Kristen. Bandung: Generasi Info Media.

Daeli Adventrianis, Nainggolan, Alon Mandimpu (2020). Persepsi Jean Charlier De Gerson dan Tuhan Yesus Kristus Mengenai pendidikan agama kristen anak. Montessori: Jurnal Pendidikan Kristen Anak Usia Dini. Vol. 1 No. 2, h. 45-57. https://ejournal-iakn-manado.ac.id/index.php/montessori/article/view/496/360.

Mayenti, Ns. Fitra. Dampak Penggunaan Gadget terhadap Perkembangan Anak Usia Dini di PAUD dan TK Taruna Islam Pekanbaru. Vol 9, No 1 Oktober 2018, 209. https://ejurnal.umri.ac.id/index.php/photon/article/view/1092. 
Nainggolan, Alon Mandimpu, Labobar Feni Yuni (2021). Menggagas Penggunaan Benih dalam Perayaan Paskah: Analisis Biblikal Yohanes 12:20-26. Epigraphe: Jurnal Teologi dan Pelayanan Kristiani. Vol. 5 No. 1. http://www.stttorsina.ac.id/jurnal/index.php/epigraphe/article/view/239. http://dx.doi.org/10.33991/epigraphe.v5i1.239.

Nainggolan, Alon Mandimpu, Harefa, Tirai Niscaya (2020). CHRISTIAN MARRIAGE SPRITUALITY: Spiritual Values in Christian Marriage. Diagesis: Jurnal $\begin{array}{llllll}\text { Teologi, Vol. } 5 & \text { No. } 1 & \text { (2020), } & \text { h. } & 1-15 .\end{array}$ http://sttbi.ac.id/journal/index.php/diegesis/article/view/28. https://doi.org/10.46933/DGS.vol5i1\%25p.

Nainggolan, Alon Mandimpu, Janis Yanice (2020). Etika Guru Agama Kristen Dan Relevansinya Terhadap Pendidikan Iman Naradidik. Caraka: Jurnal Teologi Biblika dan Praktika, Vol. 1 No. 2 (November 2020), h. 152-163. https://ojs.sttibc.ac.id/index.php/ibc/article/view/23/22. : https://doi.org/10.46348/car.v1i2.23.

Pazmino, Robert W. (1992). Fondasi Pendidikan Kristen. BPK Gunung Mulia.

Purba, Asmat. Spiritualitas Orang Tua Kristen Sebagai Pendidik Dalam Keluarga, Jurnal TEDC, [S.1.],v.15,n.2,p.134-142,may 2021. ISSN 2776-723X. Available at: http://ejournal.poltektedc.ac.id/index.php/tedc/article/478>.

Purba, Asmat. 2020. Tanggung Jawab Orang Tua Kristen dalam Mendidik Anak Menyikapi Pandemi Covid-19. Epigraphe Jurnal Teologi dan Pelayanan Kristiani, SINTA, ISSN: 2579- 9932 (online), ISSN : 2614-7203 (print). D O I: 10.33991/epigraphe.v4i1 .148. DOI:http://dx.doi.org/10.33991/epigraphe.v4i1.1 48 Volume 4 No.1 (2020).

Sidjabat, BS. (2008). Membesarkan Anak Dengan Kreatif. Yogyakarta, ANDI: 2008. , (2015). Spiritualitas Pendidik Kristen Menghadapi Postmodernisme. Jurnal Teologi Pengarah, Edisi 12 November 2015. ISSN 2087-0841.

, (1994). Strategi Pendidikan Kristen. Yogyakarta: Andi. , (2011). Membangun Pribadi Unggul. Yogyakarta: Andi, 2011.

Siregar, Uly, Anak Rewel dan Bikin Sibuk? Beri Saja Handphone...Solusi Jitukah?. https://www.google.com/amp/s/amp.dw.com/id/anak-rewel dan bikin sibuk? beri saja handphone...solusi jitukah/a-44665859.

Sugiyono, (2011). Metode Penelitian Kombinasi. Bandung: Alfabeta, 2011.

Wijanarko, Jarot (2000). Pemulihan Orangtua Anak. Jakarta: Suara Pemulihan. 